\title{
VENUS, MARS, AND BRUSSELS: LEGITIMACY AND DISPUTE SETTLEMENT CULTURE IN INVESTMENT LAW AND WTO LAW: A RESPONSE TO JOOST PAUWELYN
}

\author{
Robert Howse*
}

Late last year, the European Commission unveiled an ambitious and complex proposal to replace investorstate arbitration with a transnational court, including an appellate instance, which has now been incorporated into its new bilateral agreements with Vietnam and Canada (CETA). The Commission was responding to strong public resistance to including investor protections in the Transatlantic Trade and Investment Partnership (TTIP), the trade and investment agreement being negotiated between the European Union and the United States. This resistance reflects a remarkable shift in emphasis from the World Trade Organization (WTO) to the investment regime in what could be called loosely the antineoliberal globalization movement. The overarching concern is that international decision-makers with a neoliberal or procorporate bias will limit the policy space of sovereign states, especially in sensitive areas such as public services, the environment, health, and safety. While it is arguable that few of the actual outcomes in investor-state disputes can properly be understood in this way, the pursuit by Philip Morris of its attack on tobacco regulation through the investment regime has certainly provided a very obvious example for the activists. ${ }^{1}$ (The defeat of that challenge on jurisdictional grounds doesn't really provide assurance about the substantive norms at issue and their consistency with policy space.)

But the activists have focused as much on what they see as the biases and motivations of arbitrators as they have on the outcomes of individual cases, or the substantive norms of investor protection such as fair and equitable treatment or compensation for expropriation. Arbitrators are seen as largely coming out of the corporate law world, as an insular unaccountable incestuous elite, which is largely governed by the goal of maximizing its own financial gain from the system. ${ }^{2}$ The underlying logic of the Commission proposal would seem to be that one can address the legitimacy deficit of the investment regime by shifting from an arbitrationbased dispute settlement culture to a judicial one. This raises an important issue for intellectual inquiry-how much does the dispute settlement culture matter for the legitimacy of an international legal regime?

In the present article, ${ }^{3}$ the eminent WTO scholar Joost Pauwelyn has suggested that it matters a great deal. Noting, as observed above, that legitimacy concerns have shifted from the WTO toward the investment regime,

* Lloyd C. Nelson Professor of International Law, New York University School of Law.

Originally published online 13 April 2016.

${ }^{1}$ Philip Morris Asia Limited v. Commonwealth of Austl., PCA Case No. 2012-12.

${ }^{2}$ See for example Pia Eberhardt \& Cecilia Olivet, Profiting from Injustice: How law firms, arbitrators and financiers are fueling an investment arbitration boom (2012).

${ }^{3}$ Joost Pauwelyn, The Rule of Law without the Rule of Lawyers? Why Investment Arbitrators are from Mars, Trade Adjudicators from Venus, 109 AJIL 761 (2015). 
Pauwelyn asks whether differences between the two dispute settlement cultures might account for the fact that today the WTO does not suffer the high profile strident attacks that the investment regime now suffers from. While he does refer to the existence of an appellate instance in the WTO, Pauwelyn emphasizes that what gives enhanced legitimacy to the WTO is a system of dispute panels where the panelists are not usually legal experts but more diverse in background, assisted by a professional secretariat, and perceived to be impartial (with a large percentage of them appointed by the Secretariat). He also points to the importance of the embeddedness of the dispute settlement process in a broader system for trade where there can be political and diplomatic scrutiny and influence on the way that cases are decided, presumably a kind of control for professional biases of panelists.

If Pauwelyn is right, then the Commission may not be on the right track in thinking that an adjudication approach is the answer. While such an approach might speak to Pauwleyn's points about diversity and impartiality, depending on how the appointments process is actually designed, it is certainly at odds with his suggestion that a system composed of a large number of nonlegal experts who rarely are repeat panelists generates greater legitimacy on balance.

While recognizing the importance of Pauwelyn's work and the value of some of his insights, I want to suggest a different story about the legitimacy characteristics of the WTO dispute settlement system. This story places a great deal more emphasis on the Appellate Body and its judicial or quasi-judicial characteristics; it thus suggests that in fact the Commission may well be on to something in proposing a shift to a judicial model for the investment regime.

I begin with a striking fact: the WTO panel process has persistently produced the kind of neoliberal outcomes that led to broad and fierce criticism of the General Agreement on Tariffs and Trade and early WTO by "progressive" activists, beginning with the notorious U.S._-Tuna/Dolphin ${ }^{4}$ decision and the invention of the product/process distinction to close the door to the use of trade policy to promote global environmental values. In almost every high-profile dispute where sensitive nontrade concerns have been visibly at stake (BrazilRetreaded Tyres ${ }^{5}$ is an exception and Canada-Renewable Energy ${ }^{6}$ a partial exception), the panels have ended up siding against the government taking the policy intervention or, if they ruled in its favor, have done so on narrow or limited grounds ( $E C-A$ - Asbestos 7 ), giving little confidence that they accepted the need for policy space. And also in almost all of these cases, the Appellate Body has, even if it upheld elements of the panel ruling against the regulating state, showed in some way or another that it is more sensitive to the need for policy space, or that it would strike the balance between free trade/neoliberal values and other values in a way more favorable to the latter than would the panels. Simply naming some of the high-profile "trade and ..." cases shows the

4 Panel Report, United States-Measures Concerning the Importation, Marketing and Sale of Tuna and Tuna Products, WT/DS381/R (Adopted June 13, 2012).

5 Panel Report, Brazil-Measures Affecting Imports of Retreaded Tyres, WT/DS332/R (Adopted Dec. 17, 2007).

${ }^{6}$ Panel Report, Canada_Certain Measures Affecting the Renewable Energy Generation Sector, WT/DS412/R (Adopted May 24, 2013).

${ }^{7}$ Panel Report, European Communities_-Measures Affecting Asbestos and Products Containing Asbestos, WT/DS135/R (Adopted Apr. 5, 2001). 
prominence of this trend: EC—Hormones, ${ }^{8}$ U.S.—Shrimp/Turtle, ${ }^{9}$ EC-Asbestos, ${ }^{10}$ EC — GSP, ${ }^{11}$ Canada/U.S.— Hormones Suspension, ${ }^{12}$ EC - Seal Products. ${ }^{13}$ It is highly plausible that if the Appellate Body had not acted in this way to correct or nuance the panels, the attacks on the WTO as a bastion of neoliberal ideology would have continued in much the same way from many of the same quarters and be as strong today as those that are mounted against the investment regime.

Pauwelyn's story about the virtues of a large number of diverse, non(legal) elitist, usually nonrepeat panelists does not jive with the fact that these panelists have produced just the kind of neoliberal outcomes against which the legitimacy critique has traditionally taken aim.

The real story, to which Pauwelyn himself sometimes points by stressing the role of the Secretariat in dispute settlement, is that a revolving door of amateur, usually one-time, nonlawyer panelists produces a large degree of dependency upon the WTO legal secretariat, which is largely part of an insider trade policy community with strong neoliberal biases. As Joseph Weiler and others have pointed out, the Secretariat has very often been able to determine not just the detailed reasoning used, but the outcomes of WTO disputes. But in any case, Pauwelyn's picture of the diversity of the panelists, while seemingly better in terms of regional distribution and gender balance than in the investment regime, underestimates the significance (which he does however acknowledge) of the overlap between the legal expert panelists and the insider trade policy community: both are mostly drawn from trade ministries and WTO missions in Geneva, or are retired trade officials or negotiators. This broader epistemic community tends to presume that free or freer trade is a good thing, and is habitually suspicious of domestic regulation as hidden protectionism. In the case of the Appellate Body, however, there is much less clear overlap with the insider trade policy community, and its wealth of legal expertise and experience weakens its dependency on a professional secretariat that largely overlaps with the insider trade policy community. Pauwelyn does not really buy into this notion of a significant difference between panelists and Appellate Body members in these respects. Thus, he claims the Appellate Body is "composed mainly of ex-diplomats rather than experienced jurists." 14 In other words, their epistemic community is largely the same as the panels'. I think there is reason to question this claim. I have examined the backgrounds of all the Appellate Body members along those divisions, considering cases raising sensitive issues of policy space or valuesbalancing related to the legitimacy concerns of WTO critics (as well as others). I divide these into Pauwelyn's "ex-diplomats' on the one hand, persons whose background, like that of most panelists, is primarily as trade officials or negotiators, and who have little or no legal expertise or experience apart from their participation in the insider trade policy community (Group A), and those Appellate Body members who are or have been legal academics, who have considerable experience and expertise with legal systems other than the WTO, have played significant roles in those systems, and/or who have not spent the great bulk of their professional careers in

${ }^{8}$ Appellate Body Report, European Communities_-Measures Concerning Meat and Meat Products (Hormones), WT/DS26/AB/R, WT/DS48/AB/R (Adopted Feb. 13, 1998).

9 Appellate Body Report, United States_Import Prohibition of Certain Shrimp and Shrimp Products, WT/DS58/AB/R (Adopted Nov. 6, 1998).

10 Appellate Body Report, European Communities-Measures Affecting Asbestos and Products Containing Asbestos, WT/DS135/AB/R (Adopted Apr. 5, 2001).

11 Appellate Body Report, European Communities_Conditions for the Granting of Tariff Preferences to Developing Countries, WT/DS246/AB/R (Adopted Apr. 20, 2004).

12 Appellate Body Report, United States-Continued Suspension of Obligations in the EC-Hormones Dispute, WT/DS320/AB/R (Adopted Nov. 14, 2008); Appellate Body Report, Canada-Continued Suspension of Obligations in the ECHormones Dispute, WT/DS321/AB/R (Adopted Nov. 14, 2008).

13 Appellate Body Report, European Communities-Measures Prohibiting the Importation and Marketing of Seal Products, WT/DS400/AB/R, WT/DS401/AB/R (Adopted June 18, 2014).

14 Pauwelyn, supra note 3 , at 764 . 
trade ministries or international or regional economic institutions preoccupied with trade law and policy (Group B). The overall dominance of Group B in what I consider the policy space-sensitive, values-balancing kinds of cases is remarkable. Furthermore, in every single one of these cases there has been at least one member of Group B. Finally, even some of those I put in Group A because their professional life has been spent mostly in the trade policy insider community, would still count as "experienced jurists," for example Ramirez-Hernandez.

\begin{tabular}{|l|l|l|}
\hline \multicolumn{2}{|l|}{ EC-Hormones ${ }^{15}$} & \multicolumn{2}{l|}{} \\
\hline Feliciano & Ehlermann & Matsushita \\
\hline Group B & Group B & Group B \\
\hline
\end{tabular}

\begin{tabular}{|l|l|l|}
\hline \multicolumn{3}{|l|}{ U.S.-Shrimp/Turtle ${ }^{16}$} \\
\hline Feliciano & Bacchus & Ehlermann \\
\hline Group B & Group B & Group B \\
\hline
\end{tabular}

\begin{tabular}{|l|l|l|}
\hline EC-Asbestos ${ }^{17}$ & \\
\hline Feliciano & Bacchus & Ehlermann \\
\hline Group B & Group B & Group B \\
\hline
\end{tabular}

\begin{tabular}{|l|l|l|}
\hline EC-GSP18 \\
\hline Abi-Saab & Baptista & Sacerdoti \\
\hline Group B & Group B & Group B \\
\hline
\end{tabular}

\begin{tabular}{|l|l|l|}
\hline \multicolumn{3}{|l|}{ Canada/U.S.-Hormones Suspension ${ }^{19}$} \\
\hline Unterhalter & Bautista & Abi-Saab \\
\hline Group B & Group A & Group B \\
\hline
\end{tabular}

\begin{tabular}{|l|l|l|}
\hline EC-Seal Products & \\
\hline Graham & Chang & Zhang \\
\hline Group B & Group B & Group B \\
\hline
\end{tabular}

15 Appellate Body Report, European Communities-Measures Concerning Meat and Meat Products (Hormones), WT/DS26/AB/R, WT/DS48/AB/R (Adopted Feb. 13, 1998).

${ }^{16}$ Appellate Body Report, United States_Import Prohibition of Certain Shrimp and Shrimp Products, WT/DS58/AB/R (Adopted Nov. 6, 1998).

17 Appellate Body Report, European Communities-Measures Affecting Asbestos and Products Containing Asbestos, W'T/DS135/AB/R (Adopted Apr. 5, 2001).

18 Appellate Body Report, European Communities_Conditions for the Granting of Tariff Preferences to Developing Countries, WT/DS246/AB/R (Adopted Apr. 20, 2004).

19 Appellate Body Report, United States_Continued Suspension of Obligations in the EC-Hormones Dispute, WT/DS320/AB/R (Adopted Nov. 14, 2008); Appellate Body Report, Canada-Continued Suspension of Obligations in the ECHormones Dispute, WT/DS321/AB/R (Adopted Nov. 14, 2008).

20 Appellate Body Report, European Communities-Measures Prohibiting the Importation and Marketing of Seal Products, WT/DS400/AB/R, WT/DS401/AB/R (Adopted June 18, 2014). 


\begin{tabular}{|l|l|l|}
\hline U.S.-Clove Cigarettes & \\
\hline Oshima & Ramirez-Hernandez & Van den Bossche \\
\hline Group A & Group A & Group B \\
\hline
\end{tabular}

\begin{tabular}{|l|l|l|}
\hline U.S.-Tuna/Dolphin 22 \\
\hline Zhang & Bhatia & Graham \\
\hline Group B & Group A & Group B \\
\hline
\end{tabular}

\begin{tabular}{|l|l|l|}
\hline U.S.-Cool3 & \multicolumn{2}{l|}{} \\
\hline Bhatia & Ramirez-Hernandez & Van den Bossche \\
\hline Group A & Group A & Group B \\
\hline
\end{tabular}

\begin{tabular}{|l|l|l|}
\hline Brazil-Retreaded Tyres & \\
\hline Abi-Saab & Baptista & Tanaguchi \\
\hline Group B & Group B & Group B \\
\hline
\end{tabular}

\begin{tabular}{|l|l|l|}
\hline \multicolumn{2}{|l|}{ Canada-Renewable Energy ${ }^{25}$} \\
\hline Ramirez-Hernandez & Bhatia & Unterhalter \\
\hline Group A & Group A & Group B \\
\hline
\end{tabular}

\begin{tabular}{|l|l|l|}
\hline U.S._-Tuna/Dolphin Article 21.5 (compliance ruling) ${ }^{26}$ \\
\hline Servansing & Bhatia & Zhang \\
\hline Group A & Group A & Group B \\
\hline
\end{tabular}

Now let us consider the composition of investor-state arbitral tribunals in cases that are policy-space sensitive, or are at least perceived to have values-balancing elements. I have not yet done a comprehensive look at this, but let us take some cases that have become notorious as ones that were decided in an illegitimately proinvestor, procorporate way (not necessarily rightly characterized in that way, I emphasize).

In Metalclad ${ }^{77}$ the president of the tribunal was the distinguished public international academic Sir Elihu Lauterpacht; another member was Benjamin Civiletti, who had served as U.S. Attorney General during the Carter Administration.

21 Appellate Body Report, United States-Measures Affecting the Production and Sale of Clove Cigarettes, WT/DS406/AB/R (Adopted Apr. 4, 2012).

22 Appellate Body Report, United States-Measures Concerning the Importation, Marketing and Sale of Tuna and Tuna Products, WT/DS381/AB/R (Adopted June 13, 2012).

23 Appellate Body Report, United States_Certain Country of Origin Labelling (COOL) Requirements, WT/DS384/AB/R (Adopted July 23, 2012).

${ }^{24}$ Appellate Body Report, Brazil-Measures Affecting Imports of Retreaded Tyres, WT/DS332/AB/R (Adopted Dec. 17, 2007).

${ }_{25}$ Appellate Body Report, Canada-Certain Measures Affecting the Renewable Energy Generation Sector, WT/DS412/AB/R (Adopted May 24, 2013).

${ }^{26}$ Appellate Body Report, United States-Measures Concerning the Importation, Marketing and Sale of Tuna and Tuna Products, Recourse to Article 21.5 of the DSU by Mexico, WT/DS381/AB/RW (Adopted Dec. 3, 2015).

${ }^{27}$ Metalclad v. United Mexican States, ICSID Case No. ARB(AF)/97/1. 
In CMS v. Argentina, ${ }^{28}$ one of the arbitrators was a former career politician in the Liberal Party of Canada and former cabinet minister, another was a Brazilian judge who had sat on the International Court of Justice.

In the recent case of Bilcon v. Canada ${ }^{29}, 30$ where activists have wrongly viewed the decision in favor of the investor as intruding in legitimate environmental regulation (instead this was a case of egregious political manipulation of the regulatory process, like Metalclad) the President was a former judge of the International Court of Justice, another arbitrator was a professor of public law (whose political affiliations were on the left) and a third a distinguished professor of public international law.

My overall impression is that in the high-profile, policy space-sensitive cases, arbitral tribunals have not been dominated by members who have a corporate law/commercial arbitration professional profile. One of the super-arbitrators often perceived as favorable to arguments made by investors, Charles Brower, while associated with the White \& Case law firm, had long experience as a public law litigator and at the Iran Claims Tribunal. While there is a distinctive dispute settlement culture in investor state arbitration and a rather small self-regarding epistemic community, professional allegiance to or background in the corporate law/commercial arbitration world is not its dominant feature.

Where Pauwelyn and others are correct is to stress the possible influence of the appointment process. Arbitrators are largely appointed by the parties, investors and governments. And investor appointments are almost always, though not always, the result of choices made by the law firms that represent investors; that business is increasingly dominated by large corporate firms.

Appointments are obviously ad hoc, for a particular case. Being appointed by and paid by the parties, it would not be surprising if arbitrators often viewed their role as serving the interests of the parties in settling a particular dispute rather than maintaining the integrity of and clarifying the norms of a system of international law; it would not be surprising if they are inclined to demonstrate their suitability for appointment in future cases by investors or governments, or both. Arbitrating investor-state disputes is lucrative and it can be addictive, even for those who come out of public international law backgrounds or are full-time academics (or both). These factors may well shape who the arbitrators view as their "audience." Although this is starting to change, international investment law lacks what WTO law has developed-an interpretive community of scholars and experts, who, in a sense, mediate between the positions or concerns of outsider stakeholders and the legal development of the system through jurisprudence, who are careful critics of the jurisprudence but not in implacable ideological or principled opposition to the system as a whole. In my experience, academics working in international investment law are overwhelmingly either persons themselves interested in arbitral appointments and/or counsel work or opponents of the system as a whole The former may well be an "audience" that arbitrators pay attention to (many come out of it) but it is one that is unlikely to be sufficiently critical. The latter may well not be viewed as a relevant audience at all but rather a nuisance or mere "noise"counted as allegedly ill-informed and nonexpert.

Contrary to the impression often given by general critics or opponents of the system, arbitral awards often side with the host state in cases that are policy-space sensitive; but on the other hand, rarely do those awards articulate any kind of broad principle concerning the need for balance or the importance of not impugning legitimate general regulation. Arbitrators are uninclined to draw from general international law for normative depth. On the other hand, in cases that are policy-space sensitive, where the investor wins, arbitrators may well pull punches in the way they describe government misconduct; the most damning facts about corruption, fraud, and political bias in government behavior may be soft-peddled or left out of the public award. Metalclad is a

${ }^{28}$ CMS Gas Transmission Company v. Republic of Arg., ICSID Case No. ARB/01/8.

${ }^{29}$ Bilcon of Delaware v. Government of Can., PCA Case No. 2009-04.

${ }^{30} \mathrm{I}$ must disclose that I acted as a consultant to the investor's counsel in that case. 
great example of that: it is possible, unless one reads the lines carefully or looks between the lines, to see the case as a pure "regulatory taking" decision, indifferent to the serious consequences for publically interested regulation of finding a compensable expropriation just because the government makes legal or policy changes with expropriation-like effects on the investor. That's how activists and critics of the system have read Metalclad and it is hard to blame them too much for it. Arbitrators also often decide cases, including in favor of host governments, on jurisdictional or procedural grounds. They tend to avoid coming to clear common positions on substantive norms on matters such as national treatment/nondiscrimination, regulatory takings, or fair and equitable treatment, all instances where policy space and balancing of values are clearly at stake. The devices that arbitrators often use when they do appear to be protecting policy space, such as the reading into the North American Free Trade Agreement of a requirement of exhaustion of domestic remedies in Loewen ${ }^{31}$ or the absurd conceit in Glamis Gold 32 that one should presume customary international law has been frozen at some point close to a century ago, do not send clear messages about the policy space protected by the substantive norms or how values are or can be legitimately balanced in the interpretation and application of the substantive norms. Often how expansive or restrictive the system is in accepting investor claims is played out in arcane rulings about whether the most favored nation clause should be read as providing more favorable dispute settlement arrangements under another treaty to the investor, on what claims come under an umbrella clause, and what or who counts as an investor or investment under the treaty or the Convention on the Settlement of Investment Disputes. There are big issues here about the balance of private and public interests in global governance but few and far between are the awards that reach into the rich normative universe that is international law today to find or evolve juridical constructs that do justice to these big issues. Instead, all too often, tribunals in individual cases build obscure or formalistic sandcastles that apply to that dispute that will not ever be used again by any other arbitral tribunal.

In fairness, it is true that the Appellate Body of the WTO has sometimes been delphic in its rulings but as a standing judicial body of course, it has the chance to further clarify or nuance its previous judgments in response to reactions and criticisms.

There is at least one far-sighted super-arbitrator, Toby Landau, who has acknowledged some of the difficulties discussed above and urged the "community" to address them in the way that arbitral decisions and awards are crafted. ${ }^{33}$ But can this kind of consciousness-raising work? The question is whether the problems in question are not, as speculated above, products of the structural features of investor-state arbitration, how and why and by whom arbitrators are appointed and reappointed, how they are compensated and by whom, and thus whom they see as their "audience." If so we cannot expect that the investment arbitration "community" will wake up, even to the voice of one among them as articulate and persuasive as Landau. Instead, it may be necessary to switch to a different path. From this point of view, and especially given the experience with the WTO Appellate Body, the EU proposal for a standing judicial body merits serious consideration.

${ }^{31}$ Loewen Group v. U.S., ICSID Case No. ARB(AF)/98/3, Award, para. 217 (June 26, 2003), 7 ICSID Rep. 442 (2004).

${ }^{32}$ Glamis Gold v. U.S., Award (June 8, 2009), 48 ILM 1038 (2009)

33 See Alison Ross, Freshfields lecture 2011: Saving Investment Arbitration from Itself, Global ArBiTRATION REvIEW (Dec. 6, 2011). 